\title{
AN OVERVIEW OF RECENT DEVELOPMENTS IN TRANSLATION STUDIES WITH SPECIAL REFERENCE TO THE IMPLICATIONS FOR BIBLE TRANSLATION
}

\begin{abstract}
J.A. Naudé ${ }^{1}$
ABSTRACT

An overview of recent developments of the discipline which deals with the activity of translation, as well as the implications for Bible translation, is presented. Starting off with a discussion of the disciplinary nature of translation studies, an overview of some developments emphasising the source text, the process of translation, the reception of the translated text, and the cultural-social bound character of translation, is offered. Since the early eighties there has been a tendency within translation studies to move away from the normative and prescriptive approaches to translation and to adopt a descriptive approach towards the study of translated literature. Descriptive translation theorists attempt to account not only for textual strategies in the translated text, but also for the way in which the translation functions in the target cultural system. The implications that these recent theoretical developments have for Bible translation practice and criticism of Bible translations are arrived at in the last instance.
\end{abstract}

\begin{abstract}
Translation is a kind of transubstantiation; one poem becomes another. You can choose your philosophy of translation just as you choose how to live: the free adaptation that sacrifices detail to meaning, the strict crib that sacrifices meaning to exactitude. The poet moves from life to language, the translator moves from language to life; both, like the immigrant, try to identify the invisible, what's between the lines, the mysterious implications. (Anne Michaels - Fugitive Pieces)
\end{abstract}

\section{INTRODUCTION}

The purpose of this article is to offer a review of the developments in translation studies since the cultural turn of the early 1980s (which was also the time when the 1983 Afrikaans Bible translation was published) and to indicate the implications for Bible translation. This article updates and com-

1 Prof. J. A. Naudé, Department of Near Eastern Studies, University of the Free State, P.O. Box 339, Bloemfontein, 9300, South Africa. E-mail: naudej@ hum.uovs.ac.za 
plements the earlier articles by Naudé (2000a, 2001b). In Section 2 the emergence of translation studies as a discipline is described. Section 3 covers some of the developments in translation studies since the 1980s involving the source text, the process of translation, the reception of the translated text, and the cultural-social bound character of translation. From the very nature of things it cannot be complete but it is an effort to indicate the most important tendencies within translation studies. The fields of film translation, translation technology and machine translation (for example localisation) are not treated in this paper. Recent developments concerning literary translation, namely descriptive translation studies and corpus translation studies are treated in the article by Kruger (this volume) and do not receive full treatment in this article (see also Kruger 2000). The same pertains to the theory of Ernst-August Gutt, which is the theme of the article by Smith (this volume). The implications that recent theoretical developments have for Bible translation practice and the criticism of Bible translations are indicated in Section 4.

\section{THE EMERGENCE OF TRANSLATION STUDIES AS A DISCIPLINE}

Translation studies have emerged over the past thirty years as a new international and interdisciplinary academic field.

In the time span between the fifties and the seventies translation studies formed an integral part of applied and general linguistics which was seen as the sole source of translation studies. James Holmes (1988 [1972]: 67-80) was the first to provide a framework for this discipline and in doing so he divided it into two principal areas: on the one hand translation theory as well as the descriptive science of translation and on the other hand applied translation studies dealing with activities such as the training of translators and the provision of translation aids for translators as well as translation criticism and policy. In addition to the above mentioned distinctions, Holmes also provides for the historiography of the discipline as well as the study of the research methodology of translation studies.

Holmes invented this classification of the discipline as early as 1972, but despite this fact it has lost virtually nothing of its validity as far as modernday scholars in this field are concerned (compare for instance the classification of Snell-Hornby 1995:13-37; Van Leuven-Zwart 1992:67-157 and Baker 1998:227-280). Holmes sees a dialectical relationship between theoretical, descriptive and applied translation studies where each one provides and uses insights of the other two. On the other hand Toury (1995) does not look 
upon applied activities such as the training of translators and translation criticism as pivotal components of translation studies. He prefers to regard them as extensions of the discipline. Van Leuven-Zwart (1992) groups together theoretical and descriptive translation studies and differentiates between two broad approaches to the scientific study of translation; theory producing study ("tot licht strekkende vertaalonderzoek") (Van Leuven-Zwart 1992:60) which has as its purpose the description and exposition of the phenomenon of translation; and applied study ("tot nut strekkende vertaalonderzoek") (Van Leuven-Zwart 1992:67) which seeks to develop means and methods to serve the needs of the translator.

Especially from the eighties onwards, scholars of translation studies made use of frameworks and methodologies borrowed from other disciplines such as psychology, the theory of communication, literary theory, anthropology, philosophy and more recently cultural studies (compare Bassnett \& Lefevere 1990). During this time translation studies could be justifiably regarded as a multidisciplinary science (Snell-Hornby 1995:7-35). The distinctive methodologies and theoretical frameworks derived from other disciplines were constantly adapted and re-evaluated in order to serve the needs of translation studies as an integral and autonomous discipline. There were various distinctive theoretical perspectives from which translation may be studied for instance, a linguistic approach, a communicative /functional approach, a psycholinguistic/cognitive approach, and the polysystem theory.

During the 1990s the growing discipline of translation studies achieved a certain institutional authority, manifested tangibly by a worldwide proliferation of translator training programmes (more than 250 according to Venuti (2000:1)) and a flood of scholarly publications. At the dawn of the new millennium, translation studies is an international network of scholarly communities who conduct research and debate across conceptual and disciplinary divisions. Translation research is animated by a diverse mix of the theories that has characterised translation studies since the 1980s (polysystem, skopos, poststructuralism, feminism) and reflects developments in traditional academic disciplines such as linguistics (pragmatics, critical discourse analysis, computational corpora) as well as literary criticism, philosophy, anthropology and cultural theory (postcolonialism, sexuality, globalisation).

Baker (1993:248) argued that as a discipline, translation studies had reached a stage in its development where it was both ready for and needed the techniques and methodology of corpus linguistics in order to make a major leap from prescriptive to descriptive statements, from methodologis- 
ing to proper theorising, and from individual and fragmented pieces of research to powerful generalisations. Once this is achieved, the distinction between the theoretical and applied branches of the discipline will become clearer and more convincing.

\section{DEVELOPMENTS IN TRANSLATION STUDIES SINCE 1983}

\subsection{Linguistic-based theories of translation}

Linguistic-based theories (see Fawcett 1997) dominated translation studies when the 1983 Afrikaans Bible translation came on the stage. The dominating concept was equivalence. Nida \& Taber (1969:12) view translation as reproducing in the receptor language the closest natural equivalent of the source language first in terms of meaning and secondly in terms of style. The most familiar theoretical move of this period is a choice between translation cultivating pragmatic equivalence immediately intelligible to the receptor, i.e. sense-for-sense translation (dynamic equivalence (Nida 1964, Nida \& Taber 1969), functional equivalence (De Waard \& Nida 1986), communicative translation (Newmark 1988), covert translation (House 1981)) and translation that is formally equivalent, designed to approximate the linguistic and cultural features of the foreign text, i.e. word-for-word translation (formal equivalence (Nida 1964, Nida \& Taber 1969), semantic translation (Newmark 1988), overt translation (House 1981)). A translation is judged to be good, bad or indifferent in terms of what constitutes equivalence to the source text which is the yardstick/criterion against which translators should judge their translations.

However, inevitably owing to linguistic and cultural differences between languages, translations always fall short of the equivalence ideal. It is impossible to produce a translation, to be the mirror image of its original in accordance with the equivalence-based prescriptive/normative theories. It is inevitable in translating that a certain amount of subjectivity and reformulation is involved. The main shortcoming of prescriptive/normative translation theories is their total disregard for those sociocultural conditions under which translations are produced in order to comply with the requirements of acts of communication in the receiving culture (BassnettMcGuire 1991 [1980]; Bassnett \& Lefevere 1990). The conditions prerequisite for the attainment of equivalence differ from one language culture to another. A valid translation strategy (for example turning prose into verse or vice versa) in the past may be completely unacceptable today (Hey- 
len 1993:4). The realisation that translations are never produced in a vacuum, regardless of time and culture, and the desire to explain the time- and culture-bound criteria which are at play, result in a shift away from a normative and prescriptive methodology towards a descriptive methodology for a study of the subject (cf. Hermans 1985). This tendency within translation studies becomes noticeable from the early eighties onwards.

Varieties of linguistics continue to dominate the field in the 1990s. Linguistic-oriented theorists such as Hatim \& Mason (1990), Baker (1992) and Neubert \& Shreve (1992) draw on text linguistics, discourse analysis and pragmatics to conceptualise translation on the model of Gricean conversation. In these terms, translation means communicating the foreign text by co-operating with the target reader according to four conversational maxims: quantity of information, quality of truthfulness, relevance or consistency of context, and manner or clarity. A translation is seen as conveying a foreign message with its implicatures by exploiting the maxims of the target community. Pragmatic-based translation theories assume a communicative intention and a relation of equivalence, based on textual analysis. Translation is a semantic and pragmatic reconstruction of the source text by a top-down approach: text $>$ paragraph $>$ sentence $>$ word. It locates equivalence at a textual and communicative level, not at the sentence and lexical level. The unit of translation is the entire text. There need be no correspondences let alone equivalence between segments of the original and the translation. Words only interest the translator in so far as they are elements of the text - only texts can be translated, never words.

Ernst-August Gutt (2000 (1991)) takes a cognitive approach to translation. Communication depends on the interplay between the psychological context, i.e. the cognitive environment of an utterance (an individual's store of knowledge, values and beliefs) and the processing effort required to derive contextual effects. He extrapolates from relevance theory (Sperber and Wilson (1986)) by arguing that faithfulness in translation is a matter of communicating an intended interpretation of the foreign text through adequate contextual effects which avoid an unnecessary processing effort. The degree to which the interpretation resembles the foreign text and the means of expressing that interpretation are determined by their relevance to a target readership, their accessibility and ease of processing. Gutt claims that relevance disposes of the need for an independent theory of translation by incorporating it into the more abstract category of verbal communication. $\mathrm{He}$ asserts that the many principles, rules and guidelines of translation handed down by commentators through the centuries are in fact applications of the principle of relevance. Relevance favours a particular kind of 
translation which is clear and natural in expression in the sense that it should not be unnecessarily difficult to understand. However, words such as "adequately relevant" and "unnecessary effort" are quite vague terms that work on a sliding scale rather than a binary opposition, which make it hard to find the appropriate point on the scale.

\subsection{Process-oriented research}

Hans Krings (1986:263-275) concerns himself with the process of translation by describing the abstract mental act of translation itself. The startingpoint is a question within psycholinguistics itself: what exactly takes place in the little black box of the translator's mind as he/she creates a new, more or less matching text in another language and why is the process the way it is? In the 1990s attention is paid increasingly to the mental activity of translation. Lörscher $(1991,1996)$ and Fraser (1996) collected empirical data through think-aloud protocols, as well as interviews and questionnaires where translators are asked to verbalise their thinking during or immediately after the translation process. It affords a glimpse of the translator's intellectual labour to surmount linguistic and cultural differences, searching through problems of terminology in order to encompass questions of culture and politics. However, think-aloud protocols are beset by a number of methodical problems which should be taken into account when the data produced is put to use. Verbalisation would not register unconscious factors and automatic processes, and it can change a mental activity instead of simply reporting it. Similarly, subjects are instructed to provide specific kinds of information. Obviously the data will be affected by how articulate and self-conscious a subject may be.

Roger Bell's process model links the decoding of the original to the creation of a language-universal semantic interpretation and its subsequent reencoding as the target text through a multi-stage process involving the syntax, semantics and pragmatics of both languages. This is set within a more general model of human information-processing and systemic theory of language form and language use. Bell (1993) argued for two actions to be taken in translation theory. First of all, given the emphasis placed in the past on the evaluation of the product, it seems essential that the balance be redressed through a systematic study of the process of translation, because part of a theory of translation would account for the process of moving from original text to mental representation and how it differs from the original text. Secondly, translation theory must adopt a descriptive rather than a prescriptive approach to suit investigation of the process, function and product, recognising that the purpose of translation theory is: to reach an understanding of the 
processes undertaken in the act of translation and, not, as is so commonly misunderstood, to provide a set of norms to accomplish the perfect translation.

In short, instead of making subjective and arbitrary judgements on the extent to which one translation is "better" than the other and insisting that "goodness" resides in the faithful adherence to a body of injunctions imposed, the orientation in translation theory must be towards the objective specification of the steps and stages through which the translator works as the source text in the original language is transformed into the target text and the strategies followed; the emphasis is on the process bringing about the translation rather than on the translation itself.

\subsection{Descriptive system- and reception-oriented approaches}

The notion of literary systems contributed towards revolutionising translation studies since the 1970s. As a key constituent of many descriptive approaches, it has broken with the prescription of what translation should be, encouraging researchers to ask what translation does in specific cultural settings (cf. Hermans 1999). The most common theoretical assumption of these approaches is the relative autonomy of the translated text, that is the product of translation.

The descriptive translation theorist starts with a practical examination of a corpus of texts and then seeks to determine the norms and constraints operating on these texts in a specific culture and at a specific moment in history. In other words, the theorists attempt to account not only for textual strategies in the translated text, but also for the way in which the translation functions in the target cultural and literary system (cf. Even-Zohar 1990).

The relation between translations and their originals may be described in terms of shifts or manipulations that have occurred. For this reason one group of scholars (Gideon Toury, André Lefevere, José Lambert, Hendrik van Gorp, Theo Hermans, Susan Bassnett, etc.) is called the Manipulation School. Descriptive reception-oriented models offer a method for the comparative analysis of source and (already translated) target texts (Gentzler 1993).

\subsection{Functionalist approaches to translation}

The functionalist approaches seek to liberate translators from an excessively servile adherence to the source text, looking at translation as a new communicative act that must be purposeful with respect to the translator's client and readership. 
As an alternative to equivalence, Katharina Reiss introduced a functional category into her translation model and Hans Vermeer formulated his skopos theory in which function or aim (skopos) are key concepts. It is the intended function (skopos) of the target text which determines translation methods and strategies and not the function of the source text (Reiss \& Vermeer 1984). In this way, Vermeer dethroned both the source text as norm and the concept of equivalence. The difference between linguistic-oriented models of equivalence and Vermeer's functionalist model lies in their various attitudes towards the source text: the first group of theorists regard the source text as a norm and accord acceptability to a translation only in so far as it is equivalent to the source text. In contrast, Vermeer regards a translation as a true rendition in so far as it functions as a text in the target culture; the function of the translation in the target culture determines which aspects of the source text should be transferred to the translation. This is the reason the source text loses its function as a criterion in terms of which equivalence is measured.

Christiane Nord $(1991 ; 1997)$ provides yet another insight into the interpersonal interaction of the translation process. The initiator - who may be a client, the source text author, the target text reader or, in some cases, the translator - instigates the translation process by approaching a translator because he or she needs a certain function (or skopos) in the target culture (Nord 1991:6). This skopos is contained in the translation brief, which is the set of translating instructions issued by the client when ordering the translation. Ideally, the client would give as many details as possible about the purpose, occasion, medium, etc. the text is intended to have. A translator begins by analysing the translation skopos as contained in the initiator's brief. Then s/he finds the gist of the source text enabling him/her to determine whether the given translation task is feasible.

The next step involves a detailed analysis of the source text. It is necessary to "loop back" continually to the translation skopos, which acts as a guide to determine which source text elements can be preserved and which elements will have to be adapted. This circular process ensures that the translator takes into consideration factors relevant to the translation task. The target text should therefore fulfil its intended function in the target culture. Thus, the initiator or person playing the role of initiator actually decides on the translation skopos, even though the brief as such may be explicit about the conditions.

Any translation skopos may be formulated for a particular original and there are no limits on the translator's licence to move away from the source text. However, Nord (1997:63) makes the point that the skopos rule "is a 
very general rule which does not account for specific conventions prevalent in a particular culture community". She therefore modifies the conventional skopos theory by adding the concepts of loyalty and convention thereto in this way limiting the variety of possible functions or skopos. In Nord's (1997) view, the concept of loyalty takes account of the fact that the ultimate responsibility does not rest with the initiator, but with the translator, who in the final analysis is the only person qualified to judge whether the transfer process has taken place satisfactorily. Loyalty can be defined as "a moral category which permits the integration of culture-specific conventions into the functionalist model of translation" (Nord 1997). Loyalty implies that translators are required to take the conventions of the particular translation situation into account. In Nord's view, conventions rank below translation norms in that they are not imperative. This means that the translator is free to flout existing conventions. The combination of functionality plus loyalty means that the translator can aim at producing a functional target text which conforms to the requirements of the initiator's brief and which will be accepted in the target culture. This is contrary to equivalence-based translation theories, because the demand for faithfulness or equivalence is subordinate to the skopos rule. In other words, if the translating instructions require a change of function, source text equivalence is no longer a priority. The translator is therefore free to focus on particular aspects of the source text to the disregard of all others, if this is the requirement of the translation brief. But loyalty towards both the author and the readers of the translation compels the translator to specify exactly what aspects of the original have been taken into account and what aspects have been adapted (Nord 1992:40).

According to the functionalist approach a translation is viewed adequate if the translated text is appropriate for the communicative purpose defined in the translation brief, e.g. accessibility of the translated text.

\subsection{Culturally oriented research}

Culturally orientated research (for example the work of Bassnett \& Lefevre 1990) stems from the influence of poststructuralism and emphasises the social and historical differences of translation, and views with suspicion universals and formalisations which might have been emancipatory in the Enlightenment, but now appear totalising and repressive of local differences. The emphasis is on specific languages and discourses, cultures and sexualities and questions any universalist assumptions (see Wallmach 2000). Poststructuralist translation theory calls attention to the exclusions and hierarchies that are masked by the realist illusion of transparent language and the 
role played by translation in the creation and functioning of social movements and institutions.

\subsubsection{Postcolonial translation theory and resistive approaches to translation}

Arising from cultural anthropology in the late 1980s and early 1990s, postcolonial translation theory is based on the observation that translation has often served as an important tool of imperalism in the colonisation of peoples, the survival of colonial attitudes in the translation marketplace, and in the decolonising of the mind (Robinson 1997). Europe was seen as the original with the colonies as copies or translations of the original (Bassnett \& Trivedi 1999:4).

Momentous trends in postcolonial studies are the concepts of globalisation, tribalisation and cultural identities. On the one hand there is globalisation, which is the world-wide tendency to standardisation, where there is foreseeable, a commercially homogeneous global network linked by technology, ecology, communications and commerce. On the other hand there is the concept of a linguistic retribalisation, where people belonging to particular language and culture groups are experiencing a sometimes very violent rediscovery of their own cultural heritages (Snell-Hornby 2000). This is particularly true in some Eastern European countries, and to a certain extent this also happens in post-apartheid South Africa (see Naudé 2000b). Placed between these two poles is the concept of cultural identity. This indicates a community's awareness of and pride in its own unmistakable features and its sense of belonging. The implication is that the community can live in harmony with, and can communicate with, other communities around the world.

The implication for translation is that cultural words and concepts are utilised in the target text (i.e. the technique of foreignisation) to allow the clear demarcation of each cultural group. The terms resistancy and resistance are used by Venuti (1995) to refer to the strategy of translating a literary text in such a way that it retains something of its foreignness. This could be called a resistive approach to translation (Wallmach 2000). This approach challenges the assumption that the only valid way of translation is to produce a translation which reads fluently and idiomatically and which is so transparent in reflecting the source text author's intention in the target language that the translation could be mistaken for an original text. Derrida (2001) also questions what he calls relevant translation. He calls attention not only to its ethnocentric violence but also its simultaneous 
mystification of that violence through language that is seemingly transparent because it is univocal and idiomatic. This happens because the signifiers constituting the foreign text are replaced with another signifying chain, trying to fix a signified that can be no more than an interpretation according to the intelligibilities and interests of the receiving language and culture. Venuti's objection is reflected in the following question:

If translation fails to communicate the source text but disfigures it with the concepts and interests of the translating culture, what hope is there for a translated text to reach the ethical and political goal of building a community with foreign cultures, and a shared understanding with and of them? (Venuti 2000:341).

Venuti also joins Derrida's view that if there is no single origin, no transcendent meaning, and therefore no stable source text, one can no longer talk of translation as the transfer of meaning or as passive reproduction (Davis 2001). The autonomy of the translated text is redefined as the target-language residue which the translator releases in the hope of bridging the linguistic and cultural boundaries among readerships.

As indicated by Wallmach (2000:238), following a resistive approach to translation in practice may involve either choosing to translate a text that challenges the contemporary canon of foreign literature in the target language, or it may mean that the translator uses unidiomatic expressions and other linguistically and culturally alienating features in the translated text in order to create an impression of foreignness and provide readers of the translation with an alien reading experience.

\subsubsection{Gender-based approaches to translation}

The last thirty years of intellectual and artistic creativity in the 20th century have been marked by gender issues. Translation studies have been powerfully affected by the focus on gender. As a result of feminist praxis and criticism and the simultaneous emphasis on culture in translation studies, translation has become an important site for the exploration of the cultural impact of gender and gender-specific influence of culture (Simon 1996). With the dismantling of universal meaning and the struggle for women's presence in feminist work, and with the interest in translation as a perceptible factor in cultural change and exchange, the linking of gender and translation has created fertile ground for explorations of influence in writing, rewriting and reading. Features include critique of patriarchal language; translation practices derived from experimental feminist writing; development of openly interventionist translation practices; and translating 
as a way of recovering women's writings lost when patriarchy was the vogue (Von Flotow 1997).

Resistive approaches to translation prompt a return to basic issues in twentieth-century translation theory. The time is now ripe for a redefinition of the scope and aims of translation studies. A turning point will come as a direct consequence of access to large corpora of both original and translated texts, and of the development of specific methods and tools for interrogating such corpora in ways which are appropriate to the needs of translation scholars.

\subsection{Corpus translation studies paradigm}

Corpus linguistics, the study of language through vast computer-stored collections of texts, provides translation studies with powerful analytical tools. The first computerised corpora of translations have been created since 1995, and theorists such as Mona Baker $(1993,1996,2000)$ and Sara Laviosa (1998) have formulated concepts to analyse them. One of their goals has been to isolate the distinctive features of the language used in translations, features that are not the result of interference from the source language or simple lack of competence in the target language. This continues the interest in the autonomy of the translated text that so occupied previous decades, especially the 1980s. Corpus translation studies is thus part of the turn away from prescriptive approaches to translation towards the descriptive and cultural approaches to translation studies (Tymoczko 1998:652). Computer analysis can elucidate significant translation patterns in a corpus of foreign texts and their translations, especially if the patterns are evaluated against large reference corpora in the source and target languages. Unusual collocations of words can be uncovered in a source text so as to evaluate their handling in a translation. This kind of description might be brought to bear on cultural and social considerations.

\section{IMPLICATIONS FOR BIBLE TRANSLATION}

\subsection{Bible translation as normal translation}

The emergence of translation studies as a discipline needs to be acknowledged by Bible translation committees. In this sense Bible translation is a translational activity not substantially different from the translation of other texts belonging to a culture that is removed from the target readers in time and space. Bible translation is not a translation type in its own right, as put forward by some translation scholars (for example Wilss 
1982). The translation of the Bible is a normal translation in that it requires profound factual knowledge in addition to cultural and linguistic knowledge. This implies that new developments in this discipline must not only be taken seriously and implemented in the practice of Bible translation, but Bible translators also have to be actually trained in this field. This implies that the best translation approach available should be utilised by Bible translators. As it now stands, the functionalist approach (combined with results of corpus translation studies) is the most appropriate for translation. It also implies that Bible translators should have the command over translation competence, that is they must be trained translators. It is therefore strange that the Bible translation committee of the NIV, which is typified by Barker (1999:21) as a balanced committee does not include trained translators in its rank. Translators were chosen on the basis of their recognised expertise in the books they worked on (hermeneutics, exegetes, theologians) and church affiliation. The other group on the committee consists of English stylists and critics. A huge step forward in Bible translation is Das Neue Testament, translated by Klaus Berger, a New Testament scholar at Heidelberg University and Christiane Nord, professor in translation studies at Magdeburg. They worked on the basis of split competence. The sourceculture expert produced a draft translation in the light of more than 25 years of scholarly research in the fields of Judaism and Christianity. The translation expert considered herself as a prototypical representative of the intended audience and tried to understand and re-formulate incoherencies of the draft translation into receiver-oriented German. It was found that it had been the lack of cultural knowledge which had caused discrepancies. In these cases explanations were fitted into the translation as smoothly as possible (Nord 2002:101-102).

No new attempt at Bible translation can afford to ignore the role of translation studies as a discipline. Since translators rarely manage to achieve a sufficient depth of knowledge in the complex field of Judaism and Christianity and theologians rarely combine their factual knowledge with good translation competence, teamwork may be eminently advisable in the translation of the Bible.

\subsection{Bible translation as opening up of a foreign culture}

Translating is not a purely linguistic activity, but rather a way of facilitating communication between members of different cultures. The functionalist approach to translation was instrumental in turning culture into one of the principal concerns of modern translation theory and methodology. 
Language plays a role in its wider social and cultural context by forging and sustaining cultural practices and social structures, i.e. language entertains metonymic relations with society and culture (Talgeri \& Verma 1988). One should think of language not just of language and culture but as part and parcel of culture. The linguistic system permeates all other systems within the culture. Speaking is a culturally constructed act reflecting politeness, personhood, gender, social position, socialisation, etc. (Duranti 1997:336; Foley 1997:247-358).

One way of "opening up" a foreign culture is by way of interlingual translation. In fact, translation is regarded as the reproduction of culture in that the act of translating literary texts in particular involves transferring aspects of the culture belonging to one group to that of another. Throughout the ages translation acted as an agent of enrichment to the extent that one could trace the inception of modern national literatures, and that of minority languages in particular, back to translations of originals from prestigious literary systems. Complex and dynamic interaction between translated texts and the receiving culture's own literary production takes place. In instances where the minority literature is still young it is open to foreign influences, and translated literature can make an active and substantial contribution to the development of its language and culture. Translation is seen as the transmission of culture (cf. Venuti 1992). Bible translation played and is still playing a major role in the development of language and culture (cf. Delisle \& Woodsworth 1995:7-24; 45-54; 159-190).

The cultural distance between the source-culture author and his or her forms of expression (verbal and nonverbal), on the one hand, and any targetculture audience, on the other, is always there, even though, in some specific cases, it may not be relevant to the particular communicative act in question or so minimal that it warrants no consideration. Translators should always be aware of the culture-specificity of any form of behaviour by deeming existence of a cultural gap to be normal and its irrelevance exceptional. There are two situations that result in an intense experience of a gap between cultures (Nord 2002:99-101). Firstly, when the lack of culture-specific background knowledge makes it impossible to establish coherence between what is said and what is known. Secondly, when nonverbal and verbal behaviour do not match, due to the fact that the nonverbal behaviour cannot be interpreted correctly. These two factors impede coherence, or even render it impossible, in the reception of Biblical texts i.e. texts from which the target audience is separated by a wide cultural gap. These texts refer to a world that could not be more remote in time and space, yet their comprehension is vital for the identity and unity of Christianity today. 
Nord (1997:24-25) defines the culture barrier between two groups as consisting of rich points where differences in behaviour may cause communication conflicts. This means that, when confronted with a particular translation task, a translator has to be very sensitive towards the rich points between the groups or subgroups on either side of the language-and-culture barrier, even though it may well be decided to leave the barrier where it is and just try to assist people on either side to peep across and understand the otherness of what is happening over there (Nord 2002:102-104). This means that there may be situations in translation where it is essential to bridge the cultural gap and others where the translator is supposed to leave the gap open and insist on the cultural distance between source and target cultures (cf. postcolonial translation studies and the resistive approaches to translation). The actual choice is pragmatically defined by the purpose of the intercultural communication. In Das Neue Testament Berger and Nord (1999) present an alien culture in a way that allows readers from a culture remote in time and space to understand and respect its otherness. Nord (2001:109) illustrates how the lack of cultural knowledge lessens the appellative function of a passage, as in the following description of the New Jerusalem. The source text readers knew the colours of the precious stones mentioned, whereas this is not the case of the target text readers. For that reason the colours of the stones are added. The Today's English Version treats the source text like a technical description.

Revelation 21:18-21

\section{(i) Today's English Version}

The wall was made of jasper, and the city itself was made of pure gold, as clear as glass. The foundation-stones of the city wall were adorned with all kinds of precious stones. The first foundationstone was jasper, the second sapphire, the third agate, the fourth emerald, the fifth onyx, the sixth carnelian, the seventh yellow quartz, the eighth beryl, the ninth topaz, the tenth chalcedony, the eleventh turquoise, the twelfth amethyst. The twelve gates were twelve pearls; each gate was made from a single pearl. The street of the city was of pure gold, transparent as glass.

(ii) Das Neue Testament, 1999 (translated into English)

The city wall is made of jasper, and the city itself of gold that is as pure as glass. The foundations of the city wall are of great beauty, for they are built out of precious stones in many different colours. The first foundation-stone is green jasper, the second blue sapphire, the third red agate, the fourth light green emerald, the fifth reddish brown onyx, the sixth yellowish red carnelian, the seventh yellow-gold quartz, the eighth beryl as green as the sea, the ninth shining yellow topaz, the tenth chalcedony, shimmering greengolden, the eleventh deep red turquoise, the twelfth purple ame- 
thyst. The twelve gates are twelve pearls, each gate is made from a single pearl. The main street of the city is of gold as pure as glass.

\subsection{Bible translations for specific purposes}

The Bible includes texts belonging to a great variety of text types, which cannot fulfil the same communicative function in modern societies that they were intended for in their original social and cultural setting. Therefore, a translation of these texts can by no means rely on equivalence standards. What is needed, is a target-oriented strategy, where a new function or skopos is defined independently of the functions of the original.

From the point of view of the target literature, translation invariably implies a degree of manipulation of the source text in order to achieve a certain purpose. According to Toury (1980:55) the initial norm governs the basic choice a translator makes between adherence to the source text's structure and the source culture's norms, and striving to meet the linguistic, literary and cultural norms of the prospective new readership in the target culture. Heylen (1993:23-24) allows the translation critic to identify at least three kinds of translation:

i. Translations that make no attempt to acculturate the original work in that the translator retains as many of the foreign cultural codes as possible. Translations in this category would be source-oriented and most likely to stay on the periphery of the receiving culture.

ii. Translations that negotiate and introduce a cultural compromise by selecting those characteristics common to both source and receiving culture. Here, the translator will effect alterations to the codes of the receiving culture, while at the same time recognising existing changes. Such translations may occupy a canonised position in the receiving culture.

iii. Translations that completely acculturate the original work, with the translator adhering to the codes of the receiving culture. Translations in this category may either occupy a canonised position or stay on the periphery of the receiving culture.

In practice, however, a translation is generally a compromise between these two extremes and will be either primarily (not totally) source-oriented or primarily (not totally) target-oriented (Newmark 1988:45). The actual choice is pragmatically determined by the purpose of the intercultural communication. 
SL emphasis

Word-for-word translation

Literal translation

Faithful translation

Semantic translation
TL emphasis

Adaptation

Free translation

Idiomatic translation

Communicative translation

The development of the literary approach, which pays close attention to the specific wording of the story, causes problems for a readership with little or no knowledge of Hebrew. Existing translations often take different routes and do not allow the English reader to see the workings of the Hebrew text (cf. Rendsburg 1998). Compare the NIV translation of בִידָ (lit. in his hand) in Genesis 24:10 to the Hebrew text.

Genesis 24:10

(i) $\mathrm{BHS}$

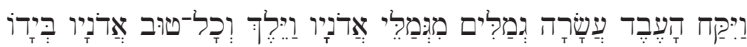

(ii) NIV

Then the servant took ten of his master's camels and left, taking with him all kinds of good things from his master.

There is no way in which Abraham's servant could have taken ten camels "in his hand". Obviously, the word בִיד means "with him", and that is how the NIV translates the text in true idiomatic fashion. But here is the point: upon closer inspection it is clear that the word T' (hand) is a keyword in the story. The servant places his hand under Abraham's thigh (v. 9), Rebekah lowers her jug on her hand (v.18), the servant places jewelry on her hand ( $\mathrm{v} 22$ ), and Laban later sees the jewelry on the hands of his sister (v 30). In the light of these usages, it is clear that the author chose 10 for additional literary effect, especially when one takes into account that other prepositions could have been utilised, namely either עתו עמו or, the simpler words for with him. This example shows that not all literary nuances of the Hebrew text are captured in the English translations. The optimal solution in this case is a source-oriented translation, presenting the text in the light of scholarly developments over the last few decades.

In the case of Das Neue Testament the overall skopos is contained in the concept of otherness understood. The appropriate translation type according to Nord (1997:48) is a documentary translation respecting the culture-specific features of both the text world and the communicative intentions of the authors and trying to make them coherent and comprehensible to a targetculture audience. 
Bible translations for special purposes, for example for deaf persons or teenagers, imply adaptations to the target text. The same pertains to a gender-based translation. Inclusive or non-sexist language aims at replacing non-motivated uses of masculine vocabulary by neutral terms: father by parent when the sex is not specified, brother by brother or sister, God the Father by God the Father-Mother, The Son of Man has become The Human One and so on. Such a principle may appear to be totally irreproachable — a sensible and an unavoidable approach to translation. And yet, some feminist scholars oppose inclusive language. They feel that this adjustment to contemporary norms in fact softens the harsh and intransigent message of a patriarchal document (Simon 1996:111-133). According to Simon (1996:133) the diversity within feminist biblical criticism will not permit a new translation from replacing existing versions.

\subsection{Utilising translation strategies instead of striving towards equivalence}

Translation occurs by way of a series of decisions made by the translator in considering the conflicting requirements of the source text and source culture on the one hand and those of the target language and target culture on the other in the light of the purpose of the intercultural communication. These concern actual decisions made in the translation process for example additions and omissions as well as textual norms revealing linguistic and stylistic preferences, which are called operational norms by Toury (1980:53-56). These categories are very broad (cf. Delabastita (1993), Newmark (1988), Williams (1990) and Baker (1992, 1993)) and a categorisation of strategies to describe the transfer of culture-specific terms might include transference, indigenisation/domestication, cultural substitution, generalisation, specification (intensification/explication), mutation (deletion and addition), etc.

As already indicated Das Neue Testament of Berger \& Nord (1999) has as its skopos the presentation of a strange culture in a way that allows readers from a culture distant in time and space to comprehend and respect its otherness. To achieve this skopos certain translation strategies were applied. Nord (2002:104-106) utilising the following passage to illustrate the translation strategies followed in various ways.

Philippians 1:1-2

(i) Today's English Version

From Paul and Timothy, servants of Christ Jesus - To all God's people in Philippi, who are in union with Christ Jesus, including the church 
leaders and helpers: May God our Father and the Lord Jesus Christ give you grace and peace.

(ii) Das Neue Testament, 1999

Paulus und Timotheus, Sklaven Jesu Christi, schreiben diesen Brief an alle Christen in Philippi, auch an alle, die dort Aufsicht führen und andere Dienste leisten. Von Gott, unserem Vater, und vom Herrn Jesus Christus geben wir Gnade und Heil an euch weiter.

[Paul and Timothy, slaves of Jesus Christ, are writing this letter to all Christians at Philippi, and to all those who are in charge and who are doing service there. We are passing on to you the mercy and salvation given by God, our Father, and our Lord Jesus Christ.]

Paul and Timothy lived in a society that knew both slaves and servants. German readers know the difference in status between a servant and a slave. It is important to note that Paul and Timothy refer to themselves as slaves so this is not a case of political correctness. If they consider themselves slaves of Jesus Christ, they refer to a property relationship. Using the word slave in this context emphasises the alien character of the culture. By paraphrasing the functions of bishops and deacons as in TEV and referring to them as church leaders and helpers, the translation seeks to avoid thoughtless equations and once again stresses cultural diversity. A bishop then in no way resembled a bishop of today. Addressing the saints in Jesus Christ and wishing them grace and peace from God, has nothing to do with foreignness of culture, but rather with foreignness of language. To be honest, the meaning of these formulae are not known, nevertheless they sound so familiar. The use of the modern word Christians for saints in Jesus Christ, which is even clearer than God's people who are in union with Christ Jesus makes the text more understandable without sacrificing anything worth preserving. The reference to Paul's authority to literally pass on God's grace and peace may give the reader an idea of the apostles' role in the early Christian society, which is not conveyed by the mere wish of the TEV.

\subsection{A descriptive instead of a normative analysis of Bible translations}

Translation theorists develop their approaches to translation criticism according to the translation models created by them (Holmes 1988[1972]: 67-80; Hulst 1988:8). In Section 3 it was shown that from the early eighties onwards a tendency became apparent in translation studies to move away from the normative approach of translation criticism, which deems a translation as good/faithful, bad or indifferent in terms of what constitutes equivalence between two texts. The focus is rather on a description and 
explanation of the translation in the light of the translator's ideology, strategies, cultural norms, etc. Lambert \& Van Gorp (1985:52-53) provide some practical guidelines for the descriptive analysis of translations and their originals. Adapted for Bible translation, the following guidelines may be followed. As a first step the researcher/critic is required to collect general information about the Bible translation. In this process the preliminary data provide information contained in the title and on the title page, and the information regarding the strategy of the translator(s) in the metatexts (such as the preface and footnotes). This supplies the introductory data enabling the researcher to form a provisional hypothesis. The second stage affords an opportunity for analysising the general macrostructural (global) features found in the Bible translation. These may include a scrutiny of the various divisions of the text, the titles of the various divisions, the internal structure, comments by the translator(s) or other directions and explanations. It is only on the third (micro-level) stage that the selected chapters are considered. The survey probes detail such as the shifts on the phonic, graphic, syntactic, stylistic and elocutionary levels, for example selection of words, dominant grammatical patterns, modality, etc. The final step in the Lambert \& Van Gorp model collects all the data from the survey and studies them in relation to the system as a whole. The entire process is viewed in terms of the target cultural system and the place it occupies in this particular system.

Another basis in terms of which texts may be compared is styled the tertium comparationis which comprises a set of parameters common to all texts, against which the degree of differentiation can be evaluated (cf. Kruger \& Wallmach 1997). A tertium comparationis will therefore comprise an independent, constant (invariable) set of dimensions in terms of which segments of the target text and source text can be compared or mapped on to each other. Concerning culture the source text can be compared to the target text according to the cultural dimensions as in Newmark (1988:103).

i. Ecology: animals, plants, local winds, etc.

ii. Material culture (artefacts): food, clothes, housing, etc.

iii. Social culture: work and leisure

iv. Organisations, customs, ideas - political, social, legal, religious, etc.

v. Gestures and habits.

Aspects of culture such as the above dimensions will then constitute the tertium comparationis. In a comparative analysis between two texts, the translation critic has to take into account a complex network of relations between, on the one hand, the source text and the political, social, cultural, 
literary and textual norms and conventions of the source system, and, on the other hand, the target texts and the political, social, cultural, literary and textual norms and conventions of the target system (cf. Hermans 1991) (cf. Naudé 1999:73-93 for an example of a comparative analysis of the Schocken Bible, Naudé 2001a for the Afrikaans Bible translations, and Wehrmeyer 2000 for the Russian Bible translations).

Corpus translation studies have the potential to be applied within the field of Bible and religious translation to study the nature of the translated text as such. Therefore corpora of Bible translations need to be created by which the general lines of investigating using notions such as equivalence, correspondence, shifts, etc. could be bypassed.

\section{CONCLUSION}

A salient characteristic of the Bible market today, and one of the major causes for the proliferation of modern versions, is that there are multiple constituencies among Bible purchasers. A distinction worth considering is the one between a translation that brings the text to the reader (i.e. target-oriented), and one that requires the reader to go to the world of the text (i.e. sourceoriented). A source-oriented translation makes far greater demands on the reader, but is of enormous value to some of the readers. This is pre-eminently the situation in many academic settings, where students can only benefit from becoming acquainted with at least some of the stylistic and formal features of the Hebrew original. On the other hand a target-oriented translation may be very helpful for first readers of the Bible or for children. As stated, it is quite impossible to produce a translated text, which is the mirror image of its original. On this point Bible translation may benefit from the functionalist model of Christiane Nord. According to this model the initiated translation skopos may act as a guide in determining which source text elements can be preserved and which elements will have to be adapted in the translation process. The article of Kruger (this volume) will indicate how corpus translation studies could supplement the functionalist approach of Bible translation. 


\section{BIBLIOGRAPHY}

\section{BAKER M}

1992. In other words: a coursebook on translation. London and New York: Routledge. 1993. Corpus linguistics and translation studies: implications and applications. In: Baker M., Francis G. \& Tognini-Bonelli E. (eds.) Text and technology: in honour of John Sinclair. Amsterdam: John Benjamins:233-250.

1996. Corpus-based translation studies: the challenges that lie ahead. In: Somers H. (ed.) Terminology, LSP and translation. Amsterdam: John Benjamins:175-186. 1998. Encyclopedia of translation studies. London \& Routledge: London.

2000. Towards a methodology for investigating the style of a literary translator. Target 12(2):241-266.

BARKER K

1999. The balance of the NIV. Grand Rapids, Mi: Baker Books.

BASSNETT S \& LEFEVERE A (eds.)

1990. Translation, history and culture. London: Pinter.

\section{BASSNETT S \& TRIVEDI H}

1999. Introduction. In: Bassnett S \& Trivedi H 1999. Postcolonial translation: theory and practice. London: Routledge:1-18.

\section{BASSNETT-MCGUIRE S}

1991 [1980]. Translation studies. 2nd revised edition. London: Methuen.

\section{BELL R T}

1993. Translation and translating. Theory and practice. London: Longman.

\section{Berger K \& Nord C}

1999. Das Neue Testament und frühchristliche Schriften, neu übersetzt und kommentiert. Frankfurt/Main: Insel Verlag.

\section{ChestermanN A}

1997. Memes of translation.Amsterdam: John Benjamins.

\section{DAVIS $\mathrm{K}$}

2001. Deconstruction and translation. Manchester, UK: St. Jerome.

\section{DELABASTITA D}

1993. There's a double tongue: an investigation into the translation of Shakespeare's wordplay, with special reference to 'Hamlet'. Amsterdam: Rodopi.

\section{DELISLE J \& WOODSWORTH J}

1995. Translators through history. Amsterdam: John Benjamins.

DERRIDA J

2001. What is a "relevant" translation? Critical Inquiry 27 (2):174-200. 
De WaARd J \& Nida E A

1986. From one language to another. Functional equivalence in Bible Translating. Nashville: Thomas Nelson Publishers.

\section{DURANTI A} 1997. Linguistic anthropology. Cambridge: Cambridge University Press.

\section{EVEN-ZOHAR I}

1990. Polysystem theory. Poetics Today 11(1):45-51.

\section{FAWCETT P}

1997. Translation and language. Linguistic theories explained. Manchester, UK: St. Jerome.

\section{FRASER J}

1996. The translator investigated: learning from translation process analysis. Translator 2:65-79.

\section{FOLEY W A}

1997. Anthropological linguistics. An introduction. Oxford: Blackwells.

\section{GENTZLER E}

1993. Contemporary translation theories. London: Routledge.

\section{GUTT E-A}

2000 (1991). Translation and relevance. Cognition and context. Manchester, UK: St. Jerome.

\section{HATIM B \& MASON I}

1990. Discourse and the translator. Longman: London \& New York.

\section{HERMANS T}

1985. Translation studies and a new paradigm. In: Hermans T. The manipulation of literature: studies in literary translation. London: Croom Helm:7-15.

1991. Translational norms and correct translations. In: Van Leuven-Zwart K. M. \& Naaijkens T. (eds.). Translation studies: the state of the art. Amsterdam: Rodopi. 1999. Translation in systems. Descriptive and system-oriented approaches explained. Manchester, UK: St. Jerome.

\section{HEYLEN R}

1993. Translation, poetics and the stage: six french 'Hamlets'. London: Routledge.

\section{HOLMES J S}

1988 [1972]. The name and nature of translation studies. In: Van den Broeck R. Translated! Papers on literary translation and translation studies. Amsterdam: Rodopi:67-80.

\section{House J}

1981. A model for translation quality assessment. Tübingen: Gunter Narr. 


\section{Hulst J S}

1988. De doeltekst central. Amsterdam: Thesis Publishers.

\section{KRINGS H P}

1986. Translation problems and translation strategies of advanced German learners of French. In: House J. \& Blum-Kulka S. Interlingual and intercultural communication: discourse and cognition in translation and second language acquisition studies. Tübingen: Gunter Narr:263-275.

\section{KRUGER A}

2000. Translation studies in South Africa at the turn of the 21st Century Language Matters 31:3-12.

\section{KRUGERR A \& WALLMACH K}

1997. Research methodology for the description of a source text and its translation(s) - a South African perspective. South African Journal of African Languages 17(4):119-126.

\section{LAMBERT J \& VAN GORP H}

1985. On describing translations. In: Hermans T. The manipulation of literature: studies in literary translation. London: Croom Helm:42-53.

\section{LÖRSCHER W}

1991. Translation performance, translation process, and translation strategies. Tübingen: Gunter Narr.

1996. A psycholinguistic analysis of the translation processes. Meta 41:26-32.

\section{NAUdÉ J A}

1999. A descriptive translation analysis of the Schocken Bible. Old Testament Essays 12(1):73-93.

2000a. Translation studies and Bible translation. Acta Theologica 20:1-27.

2000b. Review of Schäffner C. 2000. Translation in the global village. Clevedon: Multilingual Matters. Linguist List 11-2325.

2001a. The Afrikaans Bible translations and apartheid. Acta Theologica 21:106123.

2001b. Vertaalkunde vandag. 'n oorsig. Tydskrif vir Geesteswetenskappe 41(3): 177-194.

\section{Neubert A \& Shreve G M}

1992. Translation as text. Kent, Ohio: Kent State University Press.

\section{NEWMARK P}

1988. A textbook of translation. London: Pergamon.

\section{NidA E A}

1976. A framework for the analysis and evaluation of theories of translation. In: Brislin W (ed.). Translation. Applications and research. New York: Gardner Press.

NiDA E A \& TABER C

1969. The theory and practice of translation. Leiden: Brill. 
NORD C

1991. Text analysis in translation: theory, methodology, and didactic application of a model for translation-oriented text analysis. Amsterdam: Rodopi.

1992. Text analysis in translator training. In: Dollerup C \& Loddegaard A (eds.) Teaching translation and interpreting: training, talent and experience. Amsterdam: John Benjamins.

1997. Translating as a purposeful activity: functionalist approaches explained. Manchester, U.K.: St. Jerome Publishers.

2002. Bridging the cultural gap. Bible translation as a case in point. Acta Theologica 22(1):98-116.

\section{ReISS K \& VERMEER H J}

1984. Grundlegung einer Allgemeinen Translationstheorie. Tübingen: Niemeyer.

\section{RENDSBURG G}

1998. The literary approach to Bible and finding a good translation. Manuscript, Cornell University.

\section{ROBINSON D}

1997. Translation and empire. Postcolonial theories explained. Manchester, U.K.: St. Jerome Publishers.

\section{SIMON S}

1996. Gender in translation. Routledge: London.

\section{SNELL-HORNBY M}

1995. Translation studies. An integrated approach. Amsterdam: John Benjamins. 2000. Communicating in the global village: on language, translation and cultural identity. In: Schäffner C. (ed.) Translation in the global village. Clevedon: Multilingual Matters:11-28.

\section{SPERBER D \& WiLSON D}

1986. Relevance: communication and cognition. Oxford: Blackwell.

\section{TALGERI P \& VERMA S B}

1988. Literature in translation: from cultural transference to metonymic displacement. New Delhi: Sangam Books Limited.

\section{TOURY G}

1980. In search of a theory of translation. Tel Aviv: The Porter Institute for Poetics and Semiotics, Tel Aviv University.

1995. Descriptive translation studies and beyond. Amsterdam: John Benjamins.

\section{TYMOCZKO M}

1998. Computerised corpora and the future of translation studies. Meta 43(4):652-659.

\section{ULRYCH M}

1992. Translating texts. From theory to practice. Genoa: Sideb Editrice. 
VAN LEUVEN-ZWART K M

1992. Vertaalwetenschap: ontwikkelingen en perspectieven. Muiderberg: Coutinho.

\section{VENUTI L}

1992. Retbinking translation. Discourse, subjectivity, ideology. London: Routledge. 1995. The translator's invisibility: a bistory of translation. London: Routledge.

1998. The scandals of translation. Towards an ethics of difference. London: Routledge. 2000. The translation studies reader. Routledge: London.

\section{VON FLOTOW L}

1997. Translation and gender. Translating in the 'era of feminism'. Manchester, UK:

St. Jerome.

\section{WALLMACH K}

2000. 'Get them lost just as in the narrow streets of the casbah': metaphors of resistance and subversion in translation. Hermeneus 2:235-258.

\section{WEHRMEYER E}

2000. Forgive us our translations: crossing intercontinental cultural and religious boundaries. Language Matters 31:13-31.

\section{WiLLIAMS J}

1990. The translation of culture-specific terms. Lebende Sprachen 35 (2):55-58.

\section{WILSS W}

1982. The science of translation: problems and methods. Tübingen: Gunter Narr.

Keywords

Bible translation

Translation studies

Translation theory

Linguistic-based theories

Process-oriented research

Descriptive system- and reception-oriented approaches

Functionalist approaches

Culturally oriented research

Postcolonial translation theory

Resistive approaches

Gender-based approaches

Corpus translation studies 